\title{
Acute ophthalmoplegia without ataxia associated with anti-GQ1b antibody in a Chinese Gentleman
}

\author{
Helen LK Yip*, MC Kwan, WK Cheng, WY Lau \\ Neuromedical Team, Kwong Wah Hospital, Hong Kong
}

Received: May 10, 2016

Accepted: June 20, 2016

Online Published: June 28, 2016

DOI: $10.5430 /$ crim.v3n3p55

URL: http://dx.doi.org/10.5430/crim.v3n3p55

\begin{abstract}
Miller Fisher first described three patients who suffered from acute neurological illness characterized by ophthalmoplegia, areflexia and ataxia. It is considered to be a subtype of Guillain Barre Syndrome. While another subtype of GBS without ataxia was first described by Chiba et al. and is associated with isolated acute ophthalmoplegia with raised anti-GQ1b Immunoglobulin $\mathrm{G}(\mathrm{IgG})$ antibody in early phase of illness. We report a Chinese patient who presented with acute ophthalmoplegia without ataxia nor limb weakness with strongly positive anti-GQ1b IgG antibody. His neurological symptoms improved after a course of intravenous immunoglobulin (IVIg) therapy.
\end{abstract}

Key Words: Miller fisher syndrome, Acute ophthalmoplegia, Intravenous immunoglobulin, Anti-GQ1b antibody

\section{INTRODUCTION}

We report a Chinese patient who presented with acute ophthalmoplegia without ataxia associated with anti-GQ1b Immunoglobulin $\mathrm{G}(\mathrm{IgG})$ antibody which gets prompt clinical recovery after a course of immunoglobulin (IVIg) therapy.

\section{Case presentation}

A 54-year-old gentleman with past medical history of chronic hepatitis B infection put on Entecavir $0.5 \mathrm{mg}$ daily for 3 years which was regularly being followed up in our out-patient clinic.

He was admitted to Kwong Wah Hospital Medical Unit in September, 2014 for acute onset of diplopia. Physical examination upon admission revealed no external ophthalmoplegia. Bilateral pupils' sizes are equal and reactive to light. Limb muscle power, sensation and deep tendon reflexes were unremarkable. Baseline blood tests showed normal complete blood picture with normal liver and renal function tests.
Other blood tests including thyroid function, autoimmune markers (ANA, ANCA and anti-ds DNA) were negative. Computer Tomography of brain on admission was normal.

Patient developed headache with worsening diplopia 2 days after admission. Neurological examination showed right eye partial ptosis and impairment of horizontal eye gaze movement over both eyes. Limb muscle strength, deep tendon reflexes, proprioception and gait were normal.

Bedside Tensilon test was negative. Blood for antiacetylcholine receptor antibodies, HIV and Syphilis antibody were later came back to be all normal.

Magnetic resonance imaging of brain and brain stem performed on day 5 after admission showed no abnormality in both orbits and brain. Lumbar puncture examination performed on day 7 showed normal protein level with no cell count. Nerve conduction study performed over all four limbs on day 7 including all sensory, motor and F-wave were within

*Correspondence: Helen LK Yip; Email: helen_yip18@yahoo.com.hk; Address: Neuromedical Team, Kwong Wah Hospital, Hong Kong. 
normal range.

Blood for anti-GQ1b IgG titer taken at day 7 of symptoms onset came back to be strongly positive.

IVIg was commenced at dosage of $0.4 \mathrm{~g} / \mathrm{kg}$ for five consecutive days. Progressive improvement of eye muscle range of movement was demonstrated. Extraocular eye muscle movement performed 1 month later was normal.

\section{Discussion}

General approach to patient who presented with diplopia include differentiation of monocular or binocular diplopia on presentation. Most common causes of monocular diplopia are cataract, corneal shape problem or uncorrected refractive error. While the most common causes of binocular diplopia include myasthensia gravis, cranial nerve palsy, orbital infiltration etc. Clinical examination in particular to look for possibility of neuromuscular junction abnormality like eyelid ptosis, limb muscle weakness or abnormal deep tendon reflexes. Last but not least blood tests including thyroid function, electrolytes and autoimmune markers are required to exclude other medical causes of diplopia.

For our patient, he suffered from isolated acute ophthalmoparesis (AO) associated with anti GQ1b IgG antibody without ataxia nor areflexia.

It had been known to be atypical Miller Fisher syndrome (MFS). The underlying pathophysiology that accounts for the high incidence of ophthalmoplegia was related to the presence of antibodies against ganglioside GQ1b being most concentrated in extra-ocular eye muscles (cranial III, IV and VI).

Other conditions can also present with raised anti-GQ1b an- tibody titre which include Guillain-Barre syndrome (GBS) with ophthalmoplegia, Bickerstaff brainstem encephalitis and acute ophthalmoparesis without ataxia like our case.

MFS is characterized by the acute onset of external ophthalmoplegia, ataxia and areflexia. It is a subtype of GBS. Some patients who present with MFS might progress to GBS. Interestingly, patient might suffered from antecedent infections like gastrointestinal infections, upper respiratory tract infection or recent immunization prior to onset of neurological symptoms.

The differential diagnosis includes brainstem infarction, Bickerstaff's brainstem encephalitis, ocular myasthensia gravis or thyroid eye disease etc. However the clinical picture together with the radiological finding of our patient which rule out the possibility of either acute stroke or encephalitis.

Careful examination is essential for establishing the diagnosis of Miller Fisher syndrome or Acute Ophthalmoparesis (AO). Antecedent infectious symptoms in history with limitation of extraocular eye muscle movement without ataxia on physical examination are distinguishing features for $\mathrm{AO}$ as well as presence of anti-GQ1b IgG. AO is considered a milder form of Miller Fisher syndrome or a variant of Guillain-Barre Syndrome.

AO usually had good recovery with no residual neurological deficits. Literatures review in past showed IVIg will slightly hastened the amelioration of ophthalmoplegia with patient who suffered from Miller Fisher syndrome.

Our patient was given a course of IVIg in view of symptoms progression with initial acute onset of diplopia and later progressed to eyelid ptosis.

\section{REFERENCES}

[1] Chiba A, Kusunoki S, Obata H, et al. Serum anti-GQ1b antibody is associated with ophthalmoplegia in Miller Fisher syndrome and Guillain Barre syndrome: clinical and immunohistochemical studies. Neurology. 1993; 43: 1911-1917. PMid:8413947 http: //dx.doi.org/10.1212/WNL.43.10.1911

[2] Lee SH, Lim GH, Kim JS, et al. Acute ophthalmoplegia (without ataxia) associated with anti-GQ1b antibody. Neurology. 2008; 71: 426-429. PMid:18678825 http://dx .doi .org/10.1212/01.wn 1.0000324266 .95814 .74

[3] Rigamonti A, Lauria G, Longoni M, et al. Acute isolated ophthalmoplegia with anti-GQ1b antibodies. Neurol Sci. 2011; 32: 681-682.
PMid:21336874 http://dx.doi.org/10.1007/s10072-011-0 492-9

[4] Odaka M, Yuki N, Hirata K. Anti-GQ1b IG G antibody syndrome: clinical and immunological range. J Neurol Neurosurg Psychiatry. 2001; 70: 50-55. http://dx.doi.org/10.1136/jnnp.70.1.50

[5] Yuki N, Odaka M, Hirata K, et al. Aucte Ophthalmoparesis (without Ataxia) associated with anti-GQ1b Ig G antibody. Ophthalmology. 2001; 108: 196-200. http://dx.doi.org/10.1016/S0161-642 $0(00) 00420-6$

[6] Mori M, Kuwabara S, Fukutake T, et al. Intravenous immunoglobulin therapy for Miller Fisher syndrome. Neurology. 2007; 68: 1144-1146. PMid:17404197 http://dx.doi.org/10.1212/01. wnl.0000258673.31824.61 